\title{
PENGARUH KEPERCAYAAN, PERSEPSI HARGA, DAN SIKAP TERHADAP NIAT BELI KEMBALI DI SITUS LAZADA
}

\author{
Kenny Jaya Adinata ${ }^{1}$ \\ Ni Nyoman Kerti Yasa ${ }^{2}$ \\ ${ }^{1,2}$ Fakultas Ekonomi dan Bisnis Universitas Udayana, Bali, Indonesia \\ email: kennyjaya21@gmail.com
}

\begin{abstract}
ABSTRAK
Tujuan dari penelitian ini adalah menganalisis pengaruh kepercayaan, pengaruh persepsi harga, dan sikap terhadap niat beli kembali di situs Lazada.Populasi dalam penelitian ini adalah masyarakat di Kota Denpasar yang pernah berbelanja online di Lazada. Ukuran sampel 108 responden, dengan menggunakan metode Purposive Sampling. Penelitian ini dilakukan dengan teknik analisis Regresi Linier Berganda. Hasil penelitian menemukan bahwa kepercayaan, persepsi, dan sikap berpengaruh positif dan signifikan terhadap niat beli kembali di situs Lazada. Implikasi dari hasil penelitian ini adalah pertama implikasi teoritis penelitian ini dapat memperjelas hubungan pengaruh kepercayaan, persepsi harga, dan sikap terhadap niat beli kembali secara online. Kedua implikasi praktis dari penelitian ini diharapkan bisa di gunakan oleh pihak Lazada untuk menumbuhkan sikap positif kepada konsumen, menumbuhkan kepercayaan kepada konsumen, dan bisa mengkomunikasikan harga yang wajar kepada konsumen sertaa pihak Lazada dapat merumuskan strategi niat beli kembali kepada konsumen Lazada di Kota Denpasar.
\end{abstract}

Kata kunci: kepercayaan, persepsi harga, sikap dan niat beli kembali

\begin{abstract}
The purpose of this study is to analyze the effect of trust, perception of price, and attitudes on repurchase intention at Lazada site. The population in this study were Denpasar citizen who had been shopping online at Lazada. The sample size is 108 respondents, using Purposive Sampling method. This research is done by Multiple Liniear Regression analysis technique. The result of the study found that trust, perception of price, and attitudes had positive and significant effect on the repurchase intention at lazada site.Theoretical implications of this study can slarity the relantionship of influence of trust, price perceptions and attitudes toward repurchase intention. The practical implications of this research are expected to be used by the lazada to foster a positive attitudes to consumers, cultivate trust to cunsumers, and can communicate a reasonable price to consumers and the parties can formulate a strategy of repurchase intention to lazada consumers in Denpasar.
\end{abstract}

Keywords : trust, perception of price, attitudes, and repurchase intention 


\section{PENDAHULUAN}

Perkembangan teknologi informasi dan komunikasi di Indonesia semakin berkembang dan meningkat setiap tahunnya. Indonesia sendiri memiliki sekitar 132,7 juta pengguna sarana internet, dari 256,2 juta populasi penduduk Indonesia pada tahun 2016. Penggunaan internet di Indonesia cenderung meningkat dari tahun ke tahun. Pada dewasa ini banyak perusahaan yang memanfaatkan sarana teknologi internet untuk memudahkan mereka berinteraksi, bertransaksi berkomunikasi dengan konsumen. Lazada merupakan salah satu situs jual beli online yang ada di Indonesia.

Situs Lazada menawarkan solusi mudah bagi para konsumen yang hendak membeli barang via online. Lazada hanya membutuhkan waktu sekitar dua tahun untuk berhasil menempatkan diri sebagai salah satu top online retailer di Indonesia.

Tabel 1.

Data Peringkat Penggunaan Situs Belanja Online di Indonesia April 2017

\begin{tabular}{ccccccc}
\hline $\begin{array}{c}\text { Nama } \\
\text { Toko } \\
\text { Online }\end{array}$ & $\begin{array}{c}\text { Kunjungan } \\
\text { Per Bulan }\end{array}$ & $\begin{array}{c}\text { Aplikasi } \\
\text { Terinstal }\end{array}$ & Twitter & Instagram & Facebook & $\begin{array}{c}\text { Jumlah } \\
\text { Karyawan }\end{array}$ \\
\hline Lazada & 51,133 & 10,000 & 202 & 282 & 16,873 & 1,101 \\
Tokopedia & 46,533 & 10,000 & 121 & 213 & 2,632 & 885 \\
Elevenia & 34,600 & 1,000 & 124 & 108 & 1,075 & 287 \\
Bukalapak & 28,367 & 10,000 & 130 & 171 & 1,749 & 623 \\
BliBli & 25,700 & 1,000 & 418 & 88 & 3,703 & 541 \\
\hline
\end{tabular}

Sumber: iprice.co.id

Tabel 1 menunjukan data terbaru Peta E-commerce Indonesia, Pengunjung per bulan Lazada adalah 51.133.000, yang di susul oleh Tokopedia yang memiliki pengunjung per bulan sebesar 46.533.000. Lazada mencatat adanya 11.000 seller yang terdaftar pada tahun 2016 (blog.lazada.co.id). Pada tahun yang sama pihak 
Lazada mendapatkan banyak keluhan dari konsumen. Review yang di berikan oleh situs trustedcompany.com pada situs Lazada sangat kecil yaitu 1,9 dari skala 1 sampai 5. Konsumen dibuat kecewa sehingga malas berbelanja kembali di situs Lazada. Keluhan yang paling sering terjadi adalah produk yang di pesan tidak sesuai deskripsi, pesanan yang di batalkan secara sepihak oleh Lazada, sistem pengembalian yang lama dan berbelit-belit.

Komponen yang paling penting dari pembelian online adalah kepercayaan dari pelanggan ke toko online itu sendiri (Giantari et al., 2013). Keinginan serta harapan konsumen agar tercipta kepercayaan pelanggan yang akhirnya dapat menimbulkan niat membeli (Adji dan Semuel, 2014). Kepercayaan konsumen terhadap perusahaan merupakan suatu aset yang tak ternilai bagi perusahaan (Maima, 2012). Sam dan Tahir (2009) dalam penelitiannya menunjukkan bahwa kepercayaan merupakan faktor yang berpengaruh paling langsung dalam memprediksi niat pembelian kembali secara online. Kepercayaan didefinisikan sebagai sebuah keyakinan pihak akan menemukan apa yang diinginkan dari pihak lain bukan apa yang ditakutkan dari pihak lain (Mao, 2010). Selain kepercayaan, persepsi harga juga mempengaruhi niat beli kembali.

Harga adalah sejumlah uang yang dibebankan atas suatu produk atau jumlah dari nilai yang ditukar konsumen atas manfaat-manfaat memiliki dan menggunakan produk tersebut (Kotler dan Keller, 2012). Menurut Benson (2007) harga pada toko online bisa jauh lebih murah dari toko konvensional dikarenakan adanya perbedaan pada biaya sewa, sehingga dapat mempengaruhi konsumen dalan melakukan pembelian secara online. Jiang dan Bert (2005) 
menyatakan pada penelitiannya persepsi harga mempunyai pengaruh positif dan signifikan terhadap niat beli online. . Internet berpengaruh pada harga, ini dikarenakan dengan adanya internet harga menjadi standar (sutejo, 2006). Namun pada penelitan Seock dan Che-Yu (2007) menemukan bahwa variabel persepsi harga tidak berpengaruh signifikan terhadap variabel niat beli online. Adanya variabel lain selain kepercayaan dan persepsi harga yang dapat mempengaruhi niat beli kembali yaitu sikap.

Sikap seorang terhadap suatu objek ditentukan oleh keyakinan dan hasil evaluasinya terhadap objek tersebut. Motivasi untuk membeli kembali berasal dari tingginya sikap positif yang di dapat dalam suatu pembelian suatu barang atau jasa (Maima, 2012). Dwipayani dan Rahyuda (2016) sikap dapat mempengaruhi perilakunya seseorang terhadap suatu objek . Iwan (2013) menyatakan bahwa sikap konsumen menjadi faktor yang penting dalam pengambilan keputusan pembelian. Sikap adalah predisposisi yang dipelajari untuk merespon suatu obyek atau sekelompok obyek dalam suatu cara yang menyenangkan atau tidak menyenangkan secara konsisten (Suprapti, 2010:136). Hellier et al. (2003) menyatakan bahwa repurchase intention adalah keputusan terencana seseorang untuk membeli kembali suatu jasa, dengan mempertimbangan suatu situasi yang akan terjadi dan diiringi dengan tingkat kesukaan. Menurut Thamizhvanan dan Xavier (2013) niat belanja online adalah suatu keinginan dalam diri konsumen untuk melakukan transaksi secara online. Pembelian kembali memiliki sifat yang beraneka ragam sesuai dengan tingkat ketahanan yang dimiliki produk tersebut (Ndubisi dan Moi, 2005). 
Latar belakang yang telah dijabarkan, maka adapun pokok permasalahan pada penelitian ini yaitu: 1)Bagaimana pengaruh kepercayaan terhadap niat beli kembali di situs Lazada; 2)Bagaimana pengaruh persepsi harga terhadap niat beli kembali di situs Lazada; 3) Bagaimana pengaruh sikap terhadap niat beli kembali di situs Lazada?

Pokok permasalahan yang diuraikan tersebut, maka adapun tujuan pada penelitian ini yaitu: 1) Untuk menjelaskan pengaruh kepercayaan terhadap niat beli kembali di situs Lazada; 2) Untuk menjelaskan pengaruh persepsi harga terhadap niat beli kembali di situs Lazada; 3) Untuk menjelaskan pengaruh sikap terhadap niat beli kembali di situs Lazada

Manfaat teoritis hasil penelitian ini dapat menambah wawasan ilmu pengetahuan dalam rangka penerapan teori-teori yang telah di dapat di bangku perkuliahan dan dapat menambah referensi di perpustakaan Universitas Udayana serta bisa memberikan informasi khususnya mahasiswa jurusan manajemen pemasaran yang akan meneliti masalah yang sama. Manfaat praktis hasil penelitian ini diharapkan dapat memberikan masukan kepada pihak Lazada, sehingga kedepannya bisa meningkatkan lagi standar pelayanan dan keamanan Lazada agar semakin banyak masyarakat yang akan percaya dan melakukan pembelian kembali kedepannya.

Nusarika dan Purnami (2015) pada penelitianya menyatakan semakin tinggi tingkat kepercayaan maka semakin tinggi juga niat beli konsumen. Kepercayaan adalah unsur yang paling penting dalam pemasaran online, kepercayaan merupakan fondasi penting bagi konsumen untuk membeli di toko online 
(Giantari et al., 2013). Mohmed et al. (2013) menyatakan bahwa kepercayaan merupakan atribut penting yang harus diadopsi ke dalam aplikasi e-commerce. Kepercayaan dibentuk melalui kejujuran vendor website, keamanan data pribadi, dan jaminan pembayaran (Parastanti et al., 2014). Menurut Suandana et al. (2016) menyatakan bahwa semakin tinggi tingkat kepercayaan maka semakin tinggi juga terhadap niat beli.

Persepsi konsumen pada suatu harga dapat mempengaruhi keputusannya dalam pembelian suatu produk sehingga perusahaan harus mampu memberikan persepsi yang baik terhadap jasa atau produk yang akan mereka jual (Nofita, 2013). Persepsi yang baik terhadap suatu harga maka bisa mempengaruhi konsumen dalam membeli produk atau jasa pada suatu perusahaan (Nusarika dan Purnami, 2015). Resti dan Soesanto (2016) menyatakan di dalam pemasaran persepsi harga merupakan faktor yang penting dalam menciptakan minat membeli ulang terhadap jasa atau produk. Acmad \& Supriono (2017) mengemukakan bahwa semakin tinggi nilai positif persepsi harga maka akan semakin meningkatkan minat pembelian ulang. Sikap pada konsumen sering kali digambarkan sebagai hubungan antara sikap dan kepercayaan (Mowen dan Minor, 2013:249). Ain dan Ratnasari (2015) dalam penelitiannya menemukan semakin positif sikap konsumen maka niat beli kembali konsumen akan meningkat pula. Oliver dan Lee (2010), menemukan sikap konsumen merupakan faktor penting yang bisa mempengaruhi keputusan pembelian konsumen untuk suatu produk. Nilasari dan Kusumadewi (2016) dalam penelitiannya menemukan variabel sikap memiliki hasil yang positif dan signifikan tehadap niat konsumen terhadap 
produk. Menurut Anoraga (2000:228) repurchase intention merupakan suatu proses keputusan yang dilakukan konsumen yang didefinisikan sebagai sesudah melakukan pembelian atas produk tersebut. Repurchase intention menjadi kunci sukses dalam kebanyakan bisnis dan dapat mempertahankan konsumen sehingga dapat menghasilkan keuntungan bagi perusahaan (Reichheld dan Sasser, 1990). Repurchase intention merupakan penilaian individu mengenai pembelian kembali pada sebuah perusahaan yang sama, berdasarkan kejadian dan situasi yang pernah dialami (Hellier dan Geursen, 2002). Tjiptono (2004) mendefinisikan niat beli kembali merupakan suatu keinginan pelanggan untuk melakukan pembelian kembali pada kurun waktu mendatang.

Peneltian yang dilakukan oleh Nusarika dan Purnami (2015) menunjukan bahwa adanya hubungan positif antara kepercayaan dengan niat pembelian konsumen. Sam dan Tahir (2009) menyatakan adanya hubungan yang signifikan pada kepercayaan terhadap niat pembelian online. Pengujian yang di lakukan oleh Giantari et al. (2013) pada jurnalnya yang menguji variabel kepercayaan terhadap variabel niat membeli online mendapatkan hasil positif dan signifikan sebesar 0.272. Berdasarkan hasil-hasil penelitian yang telah di paparkan, maka dapat di rumuskan hipotesis sebagai berikut:

$\mathrm{H}_{1}$ : Kepercayaan berpengaruh positif dan signifikan terhadap niat beli kembali Jiang dan Bert (2005) menemukan variabel persepsi harga mempunyai pengaruh positif dan signifikan terhadap variabel pembelian online. Persamaan terjadi juga pada penelitian yang dilakukan oleh Hasslinger et al. (2013) yang menyatakan bahwa variabel harga dan variabel kepercayaan di identifikasi 
sebagai faktor penting. Berdasarkan hasil-hasil penelitian yang telah di paparkan, maka dapat di rumuskan hipotesis sebagai berikut:

$\mathrm{H}_{2}$ : Persepsi harga berpengaruh positif dan signifikan terhadap niat beli kembali Maima (2012) membuktikan dalam penelitiannya bahwa sikap memberikan pengaruh positif terhadap minat beli konsumen. Hasil penelitian yang telah dilakukan Nilasari dan Kusumadewi (2016) menemukan variabel sikap memiliki pengaruh positif dan signifikan terhadap variabel niat beli. Dewi dan Ardani (2016) juga menemukan hal yang serupa yaitu sikap berpengaruh positif signifikan terhadap niat beli ulang. Berdasarkan hasil dari penelitian yang sudah di paparkan, maka dapat di rumuskan hipotesis sebagai berikut ini:

$\mathrm{H}_{3}$ : Sikap berpengaruh positif dan signifikan terhadap Niat beli kembali

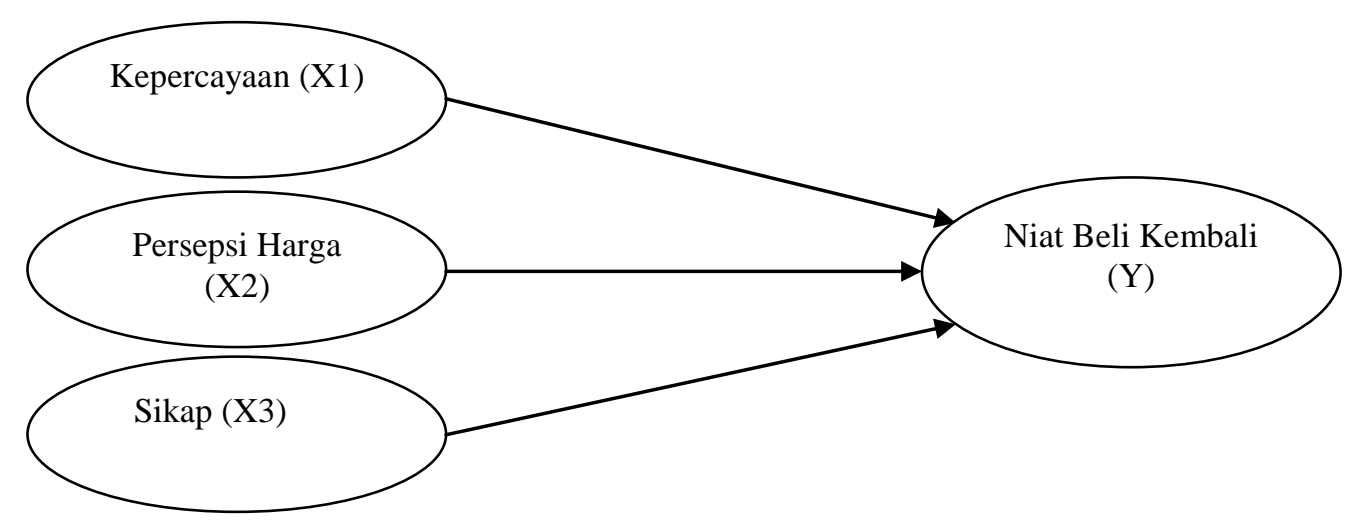

\section{Gambar 1. Kerangka Konseptual Penelitian}

Sumber: Gregg dan Walczak (2010), Becerra dan Korgaonkar (2011), Meskaran et al. (2013), Leeraphong dan Mardjo (2013), Nuseir et al. (2010), Sutejo (2006), Jiang dan Bert (2005), Hasslinger et al. (2013), Maima (2012), Mao (2010

\section{METODE PENELITIAN}

Penelitian ini menggunakan teknik non-probability sampling, dengan metode purposive sampling yaitu teknik penentuan sampel dengan pertimbangan 
syarat yang diberikan Sugiyono (2014:122). Adapun kriteria yang digunakan dalam pemilihan sampel yaitu masyarakat yang berdomisili dikota Denpasar, selesai menempuh pendidikan SMA atau sederajat sudah berumur di atas 18 tahun dan sudah pernah membeli produk secara online di situs Lazada. Data dikumpulkam melalui penyebaran instrumen penelitian yang menggunakan kuesioner dan akan diukur dengan 1 sampai 5 Skala Likert.

Jenis data kualitatif dalam penelitian ini adalah pengisian kuesioner berupa pernyataan dari para responden. Sedangkan jenis data kuantitatif dalam penelitian ini adalah angka-angka dari skala jawaban atas pernyataan dalam kuesioner yang diisi oleh responden.Penelitian ini menggunakan data primer berupa data yang didapat bersumber dari kuesioner yang disebarkan oleh peneliti terhadap responden. Data sekunder dalam penelitian ini adalah data-data yang diperoleh dari pihak ketiga yang berbentuk informasi dan dokumentasi yang diperoleh dari buku refrensi, internet, penelitian-penelitian sebelumnya hingga BPS (badan Pusat Statistik).

Pada penelitian ini yang menjadi Variabel Bebas adalah: Kepercayaan (X1), Persepsi Harga (X2) dan Sikap (X3). Penelitian ini yang menjadi variabel terikat adalah niat beli kembali (Y). Variabel-variabel yang digunakan dalam penelitian ini serta indikator variabel dapat disajikan secara ringkas pada Tabel 2. 
Tabel 2.

Variabel, Indikator, dan Sumber

\begin{tabular}{|c|c|c|c|}
\hline No & Variabel & Indikator & Sumber \\
\hline 1 & $\begin{array}{c}\text { Kepercayaan } \\
\left(\mathrm{X}_{1}\right)\end{array}$ & $\begin{array}{l}\text { 1. Ketepatan waktu pengiriman pada situs pembelian } \\
\text { online }\left(\mathrm{X}_{1.1}\right) \\
\text { 2. Kualitas produk pada situs pembelian online }\left(\mathrm{X}_{1.2}\right) \\
\text { 3. Mampu memberikan informasi yang detail pada situs } \\
\text { pembelian online }\left(\mathrm{X}_{1.3}\right) \\
\text { 4. Memiliki keamanan dalam pembelian online }\left(\mathrm{X}_{1.4}\right) \\
\text { 5. Kejujuran situs online }\left(\mathrm{X}_{1.5}\right) \\
\text { 6. Keamanan dalam situs online }\left(\mathrm{X}_{1.6}\right) \\
\text { 7. Percaya pada merek situs online }\left(\mathrm{X}_{1.7}\right)\end{array}$ & $\begin{array}{l}\text { Giantari et al. } \\
\text { (2013) }\end{array}$ \\
\hline 2 & $\begin{array}{l}\text { Persepsi Harga } \\
\text { (X2) }\end{array}$ & $\begin{array}{l}\text { 1. Harga yang akan dibayarkan sesuai dengan manfaat } \\
\text { produk yang akan dirasakan oleh konsumen }\left(\mathrm{X}_{2.1}\right) \\
\text { 2. Harga akan sesuai dengan informasi yang didapat } \\
\text { konsumen mengenai produk online }\left(\mathrm{X}_{2.2}\right) \\
\text { 3. Keterjangkauan harga produk pada situs Lazada } \\
\text { akan membuat konsumen berkeingininan untuk } \\
\text { segera membeli kembali }\left(\mathrm{X}_{2.3}\right) \\
\text { 4. Persepsi harga produk online sesuai dengan kualitas } \\
\text { produk yang diinginkan konsumen }\left(\mathrm{X}_{2.4}\right)\end{array}$ & $\begin{array}{l}\text { Nofita (2013), } \\
\text { Kotler dan } \\
\text { Armstong } \\
\text { (2008) }\end{array}$ \\
\hline 3 & $\begin{array}{l}\text { Sikap } \\
\text { (X3) }\end{array}$ & $\begin{array}{l}\text { 1. Menyukai situs online Lazada untuk melakukan } \\
\text { pembelian }\left(\mathrm{X}_{3.1}\right) \\
\text { 2. Memiliki kesan positif dalam membeli produk } \\
\text { online pada situs Lazada }\left(\mathrm{X}_{3.2}\right) \\
\text { 3. Puas menggunakan situs online Lazada untuk } \\
\text { membeli produk }\left(\mathrm{X}_{3.3}\right)\end{array}$ & Maima (2012) \\
\hline 4 & $\begin{array}{l}\text { Niat Beli } \\
\text { Kembali } \\
\text { (Y) }\end{array}$ & $\begin{array}{l}\text { 1. Ingin untuk segera membeli kembali lebih banyak } \\
\text { produk yang sama ataupun produk lain }\left(\mathrm{Y}_{1.1}\right) \\
\text { 2. Ingin untuk segera membeli kembali produk yang } \\
\text { lain }\left(\mathrm{Y}_{1.2}\right) \\
\text { 3. Ingin untuk segera membeli kembali produk yang } \\
\text { sama }\left(\mathrm{Y}_{1.3}\right) \\
\text { 4. Cenderung akan menggunakan satu situs yang sama } \\
\left(\mathrm{Y}_{1.4}\right)\end{array}$ & $\begin{array}{c}\text { Thamizhvanan } \\
\text { dan Xavier } \\
\text { (2013), } \\
\text { Tjiptono (2004) }\end{array}$ \\
\hline & Than & $\begin{array}{l}\text { (2013); Nofita (2013), Kotler dan Armstong (20 } \\
\text { dan Xavier (2013), Tjiptono (2004) }\end{array}$ & \\
\hline
\end{tabular}

Populasi dalam penelitian ini adalah masyarakat Kota Denpasar yang sudah pernah berbelanja online di situs Lazada, yang jumlahnya tidak diketahui secara pasti (infinite). Sugiyono (2014:647) menyatakan untuk memperoleh hasil yang baik ukuran sampel responden yang di ambil untuk mengisi kuesioner dapat ditentukan sedikit 5 - 10 kali jumlah indikator yang diteliti. Jumlah indikator yang diteliti dalam penelitian ini adalah sebanyak 18 indikator sehingga banyak responden yang diambil sebagai sempel adalah sebanyak 6 X $18=108$ responden. 
Pada penelitian ini dapat diambil responden sebanyak 108 orang yang sudah dapat dikatakan cukup untuk membuktikan hasil penelitian ini. Pengujian instrumen dengan uji validitas dan uji reliabilitas. Teknik analisis data dengan menggunakan analisis Regresi Linear Berganda dan di lanjutkan dengan uji Asumsi Klasik

\section{HASIL DAN PEMBAHASAN}

Karakteristik responden adalah data yang dikumpulkan untuk mengetahui profil responden peneltian.

Tabel 3.

Karakteristik Responden

\begin{tabular}{|c|c|c|c|c|c|}
\hline NO & Variabel & & Klasifikasi & $\begin{array}{l}\text { Jumlah } \\
\text { (orang) }\end{array}$ & $\begin{array}{l}\text { Persentase } \\
(\%)\end{array}$ \\
\hline \multirow{2}{*}{1} & \multirow{2}{*}{\multicolumn{2}{|c|}{ Jenis Kelamin }} & Laki-Laki & 47 & 43,5 \\
\hline & & & Perempuan & 61 & 56,5 \\
\hline \multirow{3}{*}{2} & \multirow{3}{*}{\multicolumn{2}{|c|}{ Usia }} & $18-23$ & 94 & 87,04 \\
\hline & & & $24-29$ & 10 & 9,26 \\
\hline & & & $30-35$ & 4 & 3,70 \\
\hline \multirow{4}{*}{3} & \multirow{4}{*}{\multicolumn{2}{|c|}{ Pendidikan }} & SLTA & 57 & 52,78 \\
\hline & & & Diploma & 7 & 6,48 \\
\hline & & & Sarjana (S1)" & 43 & 39,81 \\
\hline & & & Pascasarjana (S2, S3) & 1 & 0,93 \\
\hline \multirow{4}{*}{4} & \multirow{4}{*}{\multicolumn{2}{|c|}{ Alat Online }} & Smartphone & 88 & 81,48 \\
\hline & & & Laptop / Pc & 18 & 16,67 \\
\hline & & & Tablet & 0 & 0,00 \\
\hline & & & Lainnya & 2 & 1,85 \\
\hline \multirow{4}{*}{5} & \multirow{4}{*}{$\begin{array}{l}\text { Lama Waktu } \\
\text { Alat online }\end{array}$} & \multirow{4}{*}{ Mengunakan } & $<1$ jam per hari & 1 & 0,93 \\
\hline & & & 1-5 jam per hari & 8 & 7,41 \\
\hline & & & 6-10 jam per hari & 20 & 18,52 \\
\hline & & & $\begin{array}{l}\text { Selalu } \quad \text { terkoneksi } \\
\text { internet }\end{array}$ & 79 & 73,15 \\
\hline
\end{tabular}

Sumber : Data primer diolah, 2017 
Kenny Jaya Adinata, Pengaruh Kepercayaan....

Sebuah instrument dikatakan valid jika mampu mengukur apa yang seharusnya diukur, dan dapat mengungkap data dari variabel yang diteliti secara tepat. Syarat minimum untuk dianggap memenuhi syarat adalah kalau $r=0,3$ ". Instrumen dinyatakan tidak valid korelasi antara butir skor dengan skor total kurang dari 0,3 maka. Hasil uji validitas dapat dililihat pada Tabel 4 berikut ini.

Tabel 4.

\section{Hasil Uji Validitas}

\begin{tabular}{lllll}
\hline No & Variabel & Indikator & Korelasi & Keterangan \\
\hline 1 & Kepercayaan $\left(\mathrm{X}_{1}\right)$ & $\mathrm{X} 1.1$ & 0,779 & Valid \\
& $\mathrm{X} 1.2$ & 0,858 & Valid \\
& $\mathrm{X} 1.3$ & 0,876 & Valid \\
& $\mathrm{X} 1.4$ & 0,805 & Valid \\
& $\mathrm{X} 1.5$ & 0,891 & Valid \\
& $\mathrm{X} 1.6$ & 0,872 & Valid \\
& $\mathrm{X} 1.7$ & 0,879 & Valid \\
\hline & $\mathrm{X} 2.1$ & 0,901 & Valid \\
& $\mathrm{X} 2.2$ & 0,913 & Valid \\
& Persepsi Harga $\left(\mathrm{X}_{2}\right)$ & $\mathrm{X} 2.3$ & 0,871 & Valid \\
& $\mathrm{X} 2.4$ & 0,911 & Valid \\
\hline & $\mathrm{X} 3.1$ & 0,938 & Valid \\
& $\mathrm{X} 3.2$ & 0,967 & Valid \\
& & $\mathrm{X} 3.3$ & 0,940 & Valid \\
\hline 3 & Sikap $\left(\mathrm{X}_{3}\right)$ & $\mathrm{Y} .1$ & 0,829 & Valid \\
& & $\mathrm{Y} .2$ & 0,900 & Valid \\
& & $\mathrm{Y} .3$ & 0,918 & Valid \\
& & $\mathrm{Y} .4$ & 0,937 & Valid \\
\hline
\end{tabular}

Sumber : Data primer diolah, 2017

Tabel 4 menjelaskan masing - masing indikator variabel mempunyai nilai person correlation $\geq 0,3$, berarti indikator / pernyataan layak digunakan untuk mengukur dan dapat mengungkap data dari variabel yang diteliti secara tepat serta akurat.

Reliabilitas adalah suatu alat ukur berupa angka indeks yang dapat menunjukan kosistensi pada suatu alat ukur dalam mengukur gejala yang sama 
persis.. Nilai suatu insrumen dikatakan reliable bila nilai Alpha Cronbach lebih besar dari 0,6. Hasil uji reliabilitas dapat di lihat pada Tabel 5 berikut ini.

Tabel 5

Uji Reliabilitas

\begin{tabular}{llll}
\hline No & Variabel & Cronbach's Alpha & Keterangan \\
\hline 1 & Kepercayaan (X1) & 0,933 & Reliabel \\
2 & Persepsi Harga (X2) & 0,918 & Reliabel \\
3 & Sikap (X3) & 0,944 & Reliabel \\
4 & Niat Beli Kembali (Y) & 0,917 & Reliabel \\
\hline Sumber $:$ Data primer
\end{tabular}

Sumber : Data primer diolah, 2017

Tabel 5 menjelaskan bahwa nilai dari Cronbach's Alpha untuk masing masing variabel lebih dari 0,6 , ini berarti alat pengukuran tersebut akan memberikan suatu hasil yang sangat konsisten apabila alat pengukuran tersebut digunakan kembali untuk meneliti obyek yang sama persis.

Jumlah responden yang dijadikan sampel data penelitian pada masyarakat Kota Denpasar adalah sebanyak 108 orang dengan penilaian tentang kepercayaan, persepsi harga dan sikap terhadap niat beli kembali di situs Lazada Studi Pada Konsumen di Kota Denpasar, dengan masing - masing jawaban diberikan skor sebagai berikut.

1) Jawaban Sangat Setuju (SS), mendapat skor 5

2) Jawaban Setuju (S), mendapat skor 4

3) Jawaban Netral (N), mendapat skor 3

4) Jawaban Tidak Setuju (TS), mendapat skor 2

5) Jawaban Sangat Tidak Setuju (STS), mendapat skor 1

Kriteria dan kategori penilaian jawaban kuisioner pada penelitian kualitatif dipergunakan skor rata - rata jawaban responden seperti Tabel 6. 
Tabel 6.

Kriteria dan Kategori Penilaian Jawaban Kuisioner

\begin{tabular}{cc}
\hline Batas-batas Klasifikasi (Kriteria) & Kategori Penilaian \\
\hline $1,00-1,79$ & Sangat Rendah \\
$1,80-2,59$ & Rendah \\
$2,60-3,39$ & Kurang Tinggi \\
$3,40-4,19$ & Tinggi \\
$4,20-5,00$ & Sangat Tinggi \\
\hline
\end{tabular}

Sumber : Ferdinand, 2006

Variabel kepercayaan yang bisa disimbulkan dengan simbul X1, dapat diukur dengan menggunakan pernyataan yang memiliki 7 jumlah indikator dan ditanggapi menggunakan 1-5 poin Skala Likert. Tanggapan responden dapat dilihat pada Tabel 7 berikut ini.

Tabel 7.

Hasil Jawaban Responden Terhadap Kepercayaan

\begin{tabular}{|c|c|c|c|c|c|c|c|}
\hline \multirow{2}{*}{ Pernyataan } & \multicolumn{5}{|c|}{ Skor Jawaban } & \multirow{2}{*}{$\begin{array}{l}\text { Jumlah } \\
\text { Skor }\end{array}$} & \multirow{2}{*}{$\begin{array}{l}\text { Rata- } \\
\text { Rata }\end{array}$} \\
\hline & 1 & 2 & 3 & 4 & 5 & & \\
\hline $\begin{array}{l}\text { Saya percaya pada ketepatan waktu } \\
\text { pengiriminan produk yang saya beli di } \\
\text { situs Lazada }\end{array}$ & 5 & 5 & 31 & 52 & 15 & 391 & 3,62 \\
\hline $\begin{array}{l}\text { Saya percaya akan kualitas produk yang } \\
\text { saya beli di situs Lazada }\end{array}$ & 1 & 11 & 39 & 47 & 10 & 378 & 3,50 \\
\hline $\begin{array}{l}\text { Saya mengetahui pihak lazada mampu } \\
\text { memberikan informasi yang detail } \\
\text { terhadap produk yang dijualnya }\end{array}$ & 2 & 9 & 32 & 45 & 20 & 396 & 3,67 \\
\hline $\begin{array}{l}\text { Saya percaya terhadap keamanan dalam } \\
\text { melakukan pembelian online di situs } \\
\text { Lazada }\end{array}$ & 2 & 4 & 24 & 47 & 31 & 425 & 3,94 \\
\hline $\begin{array}{l}\text { Saya percaya tentang kejujuran oleh } \\
\text { pihak Lazada }\end{array}$ & 3 & 2 & 34 & 53 & 16 & 401 & 3,71 \\
\hline $\begin{array}{l}\text { Saya percaya keamanan di situs online } \\
\text { Lazada }\end{array}$ & 2 & 7 & 50 & 39 & 10 & 372 & 3,44 \\
\hline Saya percaya merek Lazada & 3 & 8 & 46 & 41 & 10 & 371 & 3,44 \\
\hline Kepercayaan (X1) & & & & & & & 3,62 \\
\hline
\end{tabular}

Sumber : Data primer diolah, 2017

Hasil pada perhitungan Tabel 7 menunjukan rata - rata jawaban responden kepercayaan. Nilai rata - rata tertinggi jawaban responden ditunjukkan pada pernyataan tentang "Saya percaya terhadap keamanan dalam melakukan pembelian online di situs Lazada" mempunyai rata - rata nilai sebesar 3,94. Rata 
rata nilai terendah sebesar 3,44 pada kedua pernyataan "Saya percaya keamanan di situs online Lazada dan Saya percaya merek Lazada”.

Variabel persepsi harga yang bisa disimbulkan dengan simbul X2, dapat diukur dengan menggunakan pernyataan yang memiliki 4 jumlah indikator dan ditanggapi menggunakan 1-5 poin Skala Likert. Tanggapan responden dapat dilihat pada Tabel 8 berikut ini.

Tabel 8.

Hasil Jawaban Responden Terhadap Persepsi Harga

\begin{tabular}{|c|c|c|c|c|c|c|c|}
\hline \multirow{2}{*}{ Pernyataan } & \multicolumn{5}{|c|}{ Skor Jawaban } & \multirow{2}{*}{$\begin{array}{c}\text { Jumlah } \\
\text { Skor }\end{array}$} & \multirow{2}{*}{$\begin{array}{l}\text { Rata } \\
\text { Rata }\end{array}$} \\
\hline & 1 & 2 & 3 & 4 & 5 & & \\
\hline Saya mengetahui bahwa harga produk & & & & & & & \\
\hline $\begin{array}{l}\text { Lazada yang akan saya bayar sesuai } \\
\text { dengan manfaat produk yang akan saya } \\
\text { rasakan }\end{array}$ & 2 & 9 & 35 & 41 & 21 & 394 & 3,65 \\
\hline Saya mengetahui bahwa harga produk & & & & & & & \\
\hline $\begin{array}{l}\text { Lazada sesuai dengan informasi yang } \\
\text { saya dapat }\end{array}$ & 2 & 13 & 28 & 43 & 22 & 394 & 3,65 \\
\hline $\begin{array}{l}\text { Saya berkeiinginan untuk membeli } \\
\text { kembali produk Lazada karena harga } \\
\text { yang di tawarkan terjangkau }\end{array}$ & 5 & 10 & 31 & 38 & 24 & 390 & 3,61 \\
\hline $\begin{array}{l}\text { Saya mempersepsikan harga produk } \\
\text { Lazada sesuai dengan kualitas produk } \\
\text { yang di tawarkan }\end{array}$ & 4 & 7 & 26 & 45 & 26 & 406 & 3,76 \\
\hline Persepsi Harga (X2) & & & & & & & 3,67 \\
\hline
\end{tabular}

Hasil pada perhitungan Tabel 8 menunjukan rata - rata jawaban responden persepsi harga. Nilai rata - rata tertinggi jawaban responden ditunjukkan pada pernyataan tentang "Saya mempersepsikan harga produk Lazada sesuai dengan kualitas produk yang di tawarkan" mempunyai nilai rata - rata sebesar 3,76. Rata - rata nilai terendah sebesar 3,61 pada pernyataan "Saya berkeiinginan untuk membeli kembali produk Lazada karena harga yang di tawarkan terjangkau”.

Variabel sikap yang dapat disimbulkan dengan simbul X3, dapat diukur dengan menggunakan pernyataan yang memiliki 3 jumlah indikator dan 
ditanggapi menggunakan 1-5 poin Skala Likert. Tanggapan responden dapat dilihat pada Tabel 9 berikut ini.

Tabel 9.

Hasil Jawaban Responden Terhadap Sikap

\begin{tabular}{|c|c|c|c|c|c|c|c|}
\hline \multirow{2}{*}{ Pernyataan } & \multicolumn{5}{|c|}{ Skor Jawaban } & \multirow{2}{*}{$\begin{array}{c}\text { Jumlah } \\
\text { Skor }\end{array}$} & \multirow{2}{*}{$\begin{array}{l}\text { Rata } \\
\text { Rata }\end{array}$} \\
\hline & 1 & 2 & 3 & 4 & 5 & & \\
\hline $\begin{array}{l}\text { Saya menyukai situs online Lazada untuk } \\
\text { melakukan pembelian }\end{array}$ & 5 & 6 & 35 & 39 & 23 & 393 & 3,64 \\
\hline $\begin{array}{l}\text { Saya memiliki kesan positif dalam } \\
\text { melakukan pembelian secara online di } \\
\text { situs Lazada }\end{array}$ & 4 & 10 & 27 & 43 & 24 & 397 & 3,68 \\
\hline $\begin{array}{l}\text { Saya puas melakukan pembelian secara } \\
\text { online di situs Lazada }\end{array}$ & 5 & 4 & 37 & 36 & 26 & 398 & 3,69 \\
\hline Sikap (X3) & & & & & & & 3,67 \\
\hline
\end{tabular}

Sumber : Data primer diolah, 2017

Hasil pada perhitungan Tabel 9 menunjukan rata - rata jawaban responden sikap. Nilai rata - rata tertinggi jawaban responden ditunjukkan pada pernyataan tentang "Saya puas melakukan pembelian secara online di situs Lazada" mempunyai nilai rata - rata sebesar 3,69. Rata-rata nilai terendah sebesar 3,64 pada pernyataan "Saya menyukai situs online Lazada untuk melakukan pembelian".

Hasil pada perhitungan Tabel 10 menunjukan rata - rata jawaban responden niat beli kembali. Nilai rata - rata tertinggi jawaban responden ditunjukkan pada pernyataan tentang "Saya Ingin untuk segera membeli kembali lebih banyak produk yang sama ataupun produk lain pada situs Lazada" mempunyai nilai rata rata sebesar 3,80. Rata-rata nilai terendah sebesar 3,41 pada pernyataan "Saya cenderung akan terus menggunakan situs belanja Lazada dalam melakukan pembelian". 
Tabel 10.

Hasil Jawaban Responden Terhadap Niat Beli Kembali

\begin{tabular}{|c|c|c|c|c|c|c|c|}
\hline \multirow{2}{*}{ Pernyataan } & \multicolumn{5}{|c|}{ Skor Jawaban } & \multirow{2}{*}{$\begin{array}{c}\text { Jumlah } \\
\text { Skor }\end{array}$} & \multirow{2}{*}{$\begin{array}{l}\text { Rata } \\
\text { Rata }\end{array}$} \\
\hline & 1 & 2 & 3 & 4 & 5 & & \\
\hline $\begin{array}{llll}\text { Saya } & \text { Ingin } & \text { untuk segera membeli }\end{array}$ & & & & & & & \\
\hline $\begin{array}{l}\text { kembali lebih banyak produk yang sama } \\
\text { ataupun produk lain pada situs Lazada }\end{array}$ & 2 & 6 & 29 & 46 & 25 & 410 & 3,80 \\
\hline $\begin{array}{l}\text { Saya Ingin untuk segera membeli } \\
\text { kembali produk yang lain pada situs } \\
\text { Lazada }\end{array}$ & 2 & 9 & 31 & 38 & 28 & 405 & 3,75 \\
\hline $\begin{array}{l}\text { Saya Ingin untuk segera membeli } \\
\text { kembali produk yang sama pada situs } \\
\text { Lazada }\end{array}$ & 6 & 12 & 30 & 40 & 20 & 380 & 3,52 \\
\hline $\begin{array}{l}\text { Saya cenderung akan terus menggunakan } \\
\text { situs belanja Lazada dalam melakukan } \\
\text { pembelian }\end{array}$ & 5 & 17 & 33 & 35 & 18 & 368 & 3,41 \\
\hline Niat Beli Kembali (Y) & & & & & & & 3,62 \\
\hline
\end{tabular}

Tabel 11.

Rangkuman Hasil Analisis Regresi Linear Berganda

\begin{tabular}{lcccc}
\hline \multirow{2}{*}{ Variabel } & \multicolumn{2}{c}{ Koefisien Regresi } & \multirow{2}{*}{ T } & \multirow{2}{*}{ Sig } \\
\cline { 2 - 3 } (constant) & B & Std. error & & 0,943 \\
Kepercayaan & & 0,266 & 0,791 \\
Persepsi Harga & 0,420 & 0,058 & 4,951 & 0,000 \\
Sikap & 0,219 & 0,089 & 2,375 & 0,019 \\
D & 0,280 & 0,117 & 2,949 & 0,004 \\
\hline
\end{tabular}

Dependen variable $\quad$ : Niat Beli Kembali

F Statistik $\quad: 85,618$

Sig F $\quad: 0,000$

$\mathrm{R}^{2} \quad: 0,712$

Adjusted $\mathrm{R}^{2} \quad: 0,703$

Sumber : Data primer diolah, 2017

Berdasarkan Tabel 11 dapat ditulis persamaan Regresi Linear Berganda sebagai berikut.

$\mathrm{Y}=0,420(\mathrm{X} 1)+0,219(\mathrm{X} 2)+0,280(\mathrm{X} 3)+\mathrm{e}$

Uji asumsi klasik sangat dilakukan untuk menguji suatu kelayakan model yang akan dibuat sebelum digunakan dalam memprediksi. Uji asumsi klasik meliputi: uji normalitas, uji multikolinearitas dan uji heteroskedastisits.

Tabel 12 menampilkan hasil uji normalitas dengan menggunakan uji kolmogorov-smirnov yang memiliki nilai signifikansi $\geq 0,05$ yaitu 0,738 oleh karena itu bisa dikatakan model regresi terdistribusi normal. 
Tabel 12.

Hasil Uji Kolmogorov-Smirnov

\begin{tabular}{|c|c|c|}
\hline & & Unstandardized Residual \\
\hline $\mathrm{N}$ & & 108 \\
\hline \multirow{2}{*}{ Normal Parameters $(a, b)$} & Mean & ,0000000 \\
\hline & Std, Deviation & 1,88195088 \\
\hline \multirow[t]{3}{*}{ Most Extreme Differences } & Absolute & 0,066 \\
\hline & Positive & 0,031 \\
\hline & Negaative & $-0,066$ \\
\hline Kolomogorov-Smirnov $Z$ & & 0,684 \\
\hline Asymp. Sig. (2-tailed) & & 0,738 \\
\hline
\end{tabular}

Tabel 13 berikut merupakan hasil olahan data untuk mengetahui hasil uji multikolinearitas.

Tabel 13.

Hasil Uji Multikolinearitas

\begin{tabular}{clcc}
\hline \multirow{2}{*}{ No } & \multirow{2}{*}{ Model } & \multicolumn{2}{c}{ Collinearity Statistic } \\
\cline { 3 - 4 } & & Tolerance & VIF \\
\hline 1 & Kepercayaan & 0,385 & 2,597 \\
2 & Persepsi Harga & 0,326 & 3,065 \\
3 & Sikap & 0,307 & 3,253 \\
\hline
\end{tabular}

Sumber : Data primer diolah, 2017

Tabel 13 menunjukan bahwa tidak terjadi multikolinearitas dalam uji regresi yang dilakukan. Hal tersebut dapat dibuktikan dari nilai VIF (Varian Inflatation Factor) yang lebih kecil dari 10 dan memiliki angka tolerance lebih dari 0,1.

Tabel 14.

Hasil Uji Heteroskedastisitas (Uji Glejser)

\begin{tabular}{llccccc}
\hline \multirow{2}{*}{ Model } & & \multicolumn{2}{c}{$\begin{array}{c}\text { Unstandardized } \\
\text { Coefficients }\end{array}$} & $\begin{array}{c}\text { Standardized } \\
\text { Coefficients }\end{array}$ & \multirow{2}{*}{ t } & \multirow{2}{*}{ Sig. } \\
\cline { 3 - 5 } & & $\mathrm{B}$ & Std. Error & Beta & & \\
\hline 1 & (Constant) & 1,258 &, 591 & & 2,129 &, 036 \\
& Kepercayaan &, 006 &, 037 &, 026 &, 168 &, 867 \\
& Persepsi Harga &, 096 &, 056 &, 288 & 1,708 &, 091 \\
& Sikap &,- 125 &, 073 &,- 297 & $-1,710$ &, 090 \\
\hline
\end{tabular}

Sumber : Data primer diolah, 2017

Tabel 14 menunjukan variabel Kepercayaan mempunyai nilai signifikansi.

0,867 >0,05, variabel Persepsi harga mempunyai nilai sig. 0,091 >0,05 dan variabel sikap mempunyai nilai sig. 0,090 >0,05. Model regresi ini tidak terjadi gejala Heteroskedastisitas. 
Analisis uji F dilakukan untuk mengetahui signifikansi variabel bebas secara simultan terhadap variabel terikat. Uji $F$ dapat dilakukan dengan cara membandingkan hasil nilai $F_{\text {hitung }}$ dengan nilai $F_{\text {tabel }}$ pada taraf signifikansi 0,05 . Perhitungan regresi linear berganda yang telah dilakukan mendapatkan nilai $F_{\text {hitung }}$ sebesar 85,618 dan nilai $\mathrm{F}_{\text {tabel }}$ dengan tingkat keyakinan 95\% dan $\alpha=0,05 ; \mathrm{df}=$ $(\mathrm{k}-1):(\mathrm{n}-\mathrm{k})=(3: 104)$ adalah sebesar $2,69$. Oleh karena $F_{\text {hitung }}(85,618)$ lebih besar dari $\mathrm{F}_{\text {tabel }}(2,69)$ dengan nilai signifikansi $0,000<0,05$ memiliki arti bahwa kepercayaan, persepsi harga dan sikap berpengaruh secara positif dan signifikan terhadap niat beli kembali pada situs Lazada di Kota Denpasar. Koefisien determinasi dengan nilai 0,712 mempunyai arti bahwa sebesar $71,2 \%$ variasi pada niat beli kembali dapat dijelaskan oleh kepercayaan, persepsi harga dan sikap sedangkan sisa sebesar $28,8 \%$ dipengaruhi oleh variabel-variabel lain yang tidak di masukan dalam model penelitian ini.

Analisis uji t dilakukan untuk mengetahui signifikansi variabel bebas secara parsial terhadap variabel terikat. Uji $\mathrm{t}$ dapat dilakukan dengan cara membandingkan hasil nilai $t_{\text {hitung }}$ dengan nilai $t_{\text {tabel }}$ pada taraf signifikansi 0,05 dengan pengujian $\alpha=0,05 ; \mathrm{df}=104$, sehingga $t_{\text {tabel }}(0,05: 104)$ adalah sebesar 1,660. Tabel 15 menunjukan hasil perhitungan analisis uji t.

Tabel 15.

Hasil Analisis Uji t

\begin{tabular}{cccccc}
\hline Variabel & $\mathbf{t}_{\text {hitung }}$ & $\mathbf{t}_{\text {tabel }}$ & Hasil Uji t & Sig. & Hasil Hipotesis \\
\hline X1 & 4,951 & 1,660 & $(4,951)>(1,660)$ & 0,000 & $\mathrm{H}_{0}$ ditolak \\
X2 & 2,375 & 1,660 & $(2,375)>(1,660)$ & 0,019 & $\mathrm{H}_{0}$ ditolak \\
X3 & 2,949 & 1,660 & $(2,949)>(1,660)$ & 0,004 & $\mathrm{H}_{0}$ ditolak \\
\hline
\end{tabular}

Sumber : Data primer diolah, 2017 


\section{Pembahasan Hasil Penelitian}

Penelitian ini memiliki tujuan yang pertama yaitu menjelaskan pengaruh kepercayaan terhadap niat beli kembali di situs Lazada. Rangkuman hasil analisis Regresi Linear Berganda pada tabel 11 menunjukan tingkat signifikansi kepercayaan sebesar $0,000<0,05$, dengan nilai beta 0,289 , mempunyai arti kepercayaan berpengaruh positif dan signifikan terhadap niat beli kembali. Hipotesis pertama yang menyatakan bahwa kepercayaan berpengaruh positif dan signifikan terhadap niat beli kembali dapat di terima, yang berarti semakin tinggi tingkat kepercayaan maka dapat meningkatkan niat beli kembali di situs Lazada di Kota Denpasar.

Variabel Kepercayaan $\left(\mathrm{X}_{1}\right)$ yang diukur dengan menggunakan tujuh indikator yaitu Ketepatan waktu pengiriman pada situs pembelian online $\left(\mathrm{X}_{1.1}\right)$, Kualitas produk pada situs pembelian online $\left(\mathrm{X}_{1.2}\right)$, Mampu memberikan informasi yang detail pada situs pembelian online $\left(\mathrm{X}_{1.3}\right)$, Memiliki keamanan dalam pembelian online $\left(\mathrm{X}_{1.4}\right)$, Kejujuran situs online $\left(\mathrm{X}_{1.5}\right)$, Keamanan dalam situs online $\left(\mathrm{X}_{1.6}\right)$,dan Percaya pada merek situs online $\left(\mathrm{X}_{1,7}\right)$. Hasil penelitian ini searah dengan pernyataan Nusarika dan Purnami (2015) menunjukan bahwa adanya hubungan positif antara kepercayaan dengan niat beli konsumen secara online. Sam dan Tahir (2009) menyatakan adanya hubungan yang signifikan pada kepercayaan terhadap niat pembelian online. Becerra dan Korgaonkar (2011) menemukan bahwa kepercayaan berkontribusi positif terhadap keberhasilan transaksi online. Pengujian yang di lakukan oleh Giantari et al. (2013) pada 
jurnalnya yang menguji variabel kepercayaan terhadap variabel niat membeli online mendapatkan hasil positif dan signifikan.

Penelitian ini memiliki tujuan yang kedua yaitu menjelaskan pengaruh persepsi harga terhadap niat beli kembali di situs Lazada. Rangkuman hasil analisis Regresi Linear Berganda pada tabel 11 menunjukan tingkat signifikansi persepsi harga sebesar $0,019<0,05$, dengan nilai beta 0,212 , mempunyai arti persepsi harga berpengaruh positif dan signifikan terhadap niat beli kembali. Hipotesis kedua yang menyatakan bahwa persepsi harga berpengaruh positif dan signifikan terhadap niat beli kembali dapat di terima, yang berarti semakin baik tingkat persepsi harga maka dapat meningkatkan niat beli kembali di situs Lazada di Kota Denpasar

Variabel persepsi harga $\left(\mathrm{X}_{2}\right)$ yang diukur dengan menggunakan empat indikator yaitu Harga yang akan dibayarkan sesuai dengan manfaat produk yang akan dirasakan oleh konsumen $\left(\mathrm{X}_{2.1}\right)$, Harga akan sesuai dengan informasi yang didapat konsumen mengenai produk online $\left(\mathrm{X}_{2.2}\right)$, Keterjangkauan harga produk pada situs Lazada akan membuat konsumen berkeingininan untuk segera membeli kembali $\left(\mathrm{X}_{2.3}\right)$, dan Persepsi harga produk online sesuai dengan kualitas produk yang diinginkan konsumen $\left(\mathrm{X}_{2.4}\right)$. Hasil Penelitian ini mendukung pernyataan Jiang dan Bert (2005) yang menyatakan bahwa persepsi harga berpengaruh positif dan signifikan terhadap pembelian online. Persamaan terjadi juga pada penelitian yang dilakukan oleh Hasslinger et al. (2013) yang menyatakan bahwa harga, kepercayaan dan kenyamanan di identifikasi sebagai faktor penting dalam melakukan pembelian secara online. 
Penelitian ini memiliki tujuan yang ketiga yaitu menjelaskan pengaruh sikap terhadap niat beli kembali di situs Lazada. Rangkuman hasil analisis Regresi Linear Berganda pada tabel 11 menunjukan tingkat signifikans sikap sebesar $0,004<0,05$, dengan nilai beta 0,344 , mempunyai arti persepsi harga berpengaruh positif dan signifikan terhadap niat beli kembali. Hipotesis ketiga yang menyatakan bahwa sikap berpengaruh positif dan signifikan terhadap niat beli kembali dapat di terima, yang berarti semakin positif sikap maka dapat meningkatkan niat beli kembali di situs Lazada di Kota Denpasar

Variabel sikap $\left(\mathrm{X}_{3}\right)$ yang diukur dengan menggunakan tiga indikator yaitu Menyukai situs online Lazada untuk melakukan pembelian $\left(\mathrm{X}_{3.1}\right)$, Memiliki kesan positif dalam membeli produk online pada situs Lazada $\left(\mathrm{X}_{3.2}\right)$, dan Puas menggunakan situs online Lazada untuk membeli produk $\left(\mathrm{X}_{3.3}\right)$. Hasil ini mendukung penelitian yang dilakukan oleh Maima (2012) yang menyatakan bahwa sikap berpengaruh positif terhadap minat beli konsumen. Studi berbeda yang Mao (2010) menunjukan sikap mencerminkan kepercayaan konsumen untuk melakukan pembelian produk secara online. Pada Penelitian yang dilakukan Nilasari dan Kusumadewi (2016) menemukan sikap berpengaruh positif dan signifikan terhadap niat beli konsumen. Dewi dan Ardani (2016) juga menemukan hal yang serupa yaitu sikap berpengaruh positif signifikan terhadap niat beli ulang, Ini berarti bahwa apabila sikap konsumen baik, maka niat beli ulang konsumen akan meningkat. 


\section{Implikasi Hasil Penelitian}

Pertama implikasi teoritis penelitian ini menghasilkan simpulan mengenai bagaimana kepercayaan, persepsi harga dan sikap mempengaruhi niat beli kembali di situs Lazada. Hasil memberikan wawasan dalam memaksimalkan niat beli kembali berdasarkan kepercayaan, persepsi harga dan sikap. Penelitian ini membuktikan bahwa belanja online memerlukan tingkat kepercayaan yang tinggi untuk memperoleh konsumen yang akan melakukan pembelian secara berulang, selain kepercayaan perlu memperhatikan persepsi harga dan sikap dalam melakukan transaksi belanja online agar konsumen dapat dengan yakin melakukan pembelian ulang dalam situs Lazada khususnya di Kota Denpasar.

Kedua implikasai praktis penelitian ini diharapkan dapat memberikan kontribusi positif bagi semua pihak yang berkepentingan khususnya konsumen yang sudah melakukan transaksi pada situs online Lazada. Penelitian ini diharapkan mampu memberikan informasi yang digunakan sebagai pertimbangan dalam melakukan keputusan untuk belanja online kembali bagi konsumen.

\section{Keterbatasan Penelitian}

Penelitian ini memiliki beberapa keterbatasan yang bisa mempengaruhi kondisi dari penelitian yang dilakukan. Pada penyebaran kuisioner hanya sebatas ruang lingkup wilayah Kota Denpasar, Maka hasil penelitian ini tidak dapat digeneralisir untuk konsumen lainnya yang berada di luar wilayah Kota Denpasar serta tidak mampu digunakan untuk pembelian produk secara online pada situs toko online lainnya. Belum dimasukannya variabel lain yang dapat mempengaruhi 
niat beli kembali seperti pesan iklan, diskon, loyalitas, celebrity endorse dan lainnya.

\section{SIMPULAN DAN SARAN}

Berdasarkan pada pembahasan pada bab - bab sebelumnnya, maka adapun hal - hal yang dapat disimpulkan sebagai berikut: 1) Kepercayaan berpengaruh positif dan signifikan terhadap niat beli kembali di situs Lazada di Kota Denpasar. Dengan indikator tertinggi "Saya percaya terhadap keamanaan dalam melakukan pembelian online di situs Lazada", ini berarti bahwa konsumen memiliki kepercayaan tinggi dalam melakukan pembelian online di situs Lazada, maka dari itu dapat disimpulkan bahwa semakin tinggi kepercayaan konsumen akan pembelian online semakin tinggi juga niat beli kembali konsum pada situs Lazada di Kota Denpasar. 2) Persepsi harga berpengaruh positif dan signifikan terhadap niat beli kembali di situs Lazada di Kota Denpasar. Dengan indikator tertinggi "Saya mempersepsikan harga produk Lazada sesuai dengan kualitas produk yang ditawarkan", ini berarti bagi konsumen harga produk yang sesuai dengan kualitas produk yang ditawarkan oleh pihak Lazada membuat mereka untuk melakukan pembelian kembali. Maka semakin baik persepsi konsumen akan produk maka semakin tinggi pula niat beli konsumen tersebut di Kota Denpasar. 3) Sikap berpengaruh positif dan signifikan terhadap niat beli kembali di situs Lazada di Kota Denpasar. Dengan indikator tertinggi "Saya puas melakukan pembelian online di situs Lazada", ini berarti konsumen meraasa bahwa transaksi yang dilakukan sesuai dengan harapannya. Maka semakin positif 
sikap konsumen semakin tinggi juga niat beli konsumen tersebut pada situs Lazada di Kota Denpasar.

Berdasarkan kesimpulan tersebut, maka adapun saran - saran yang dapat diberikan adalah sebagai berikut: 1) Berdasarkan indikator terendah dari penelitian ini memberikan saran bagi pihak Lazada untuk mempertahankan kepercayaan konsumen pada pihak Lazada dan keamanan pada saat transaksi online. Pihak Lazada juga diharapkan dapat memperhatikan harga yang ditentukan pada produknya agar konsumen dapat menjangkau harga produk yang ditetapkan oleh pihak Lazada. Selain itu pihak Lazada diharapkan dapat menarik perhatian konsumen untuk melakukan pembelian online kembali di situs Lazada. 2) Bagi Peneliti selanjutnya hendaknya menambah variabel lainnya seperti loyalitas, promosi, iklan, celebrity endorse sehingga dapat menimbulkan niat beli kembali pada situs Lazada di Kota Denpasar. Variabel demografi dapat dijadikan sebagai pemoderasi sehingga diperoleh hasil penelitian yang optimal pada penelitian selanjutnya. Penambahan jumlah sampel dan memperluas ruang lingkup penelitian yang tidak hanya terbatas di Kota Denpasar saja.

\section{REFERENSI}

Acmad, F. \& Supriono, 2017. Pengaruh Persepsi Harga Dan Kualitas Layanan Terhadap Minat Pembelian Ulang (Survei pada Konsumen Go-ride di Kota Surabaya). Jurnal Administrasi Bisnis (JAB), 50(2), pp.135 - 141.

Adji, J. \& Semuel, H., 2014. Pengaruh Satisfaction dan Trust Terhadap Minat Beli Konsumen (Purchase Intention) di Starbucks The Square Surabaya. Jurnal Manajemen Pemasaran Petra, 2(1), pp.1-10. 
Ain, N. \& Ratnasari, R.T., 2015. Pengaruh Citra Merek Melalui Sikap Konsumen Terhadap Niat Beli Ulang Pada Produk Busana Muslim Zoya Di Surabaya. JESTT , 2(7), pp.553 - 569.

Anogara, P., 2000. Manajemen Bisnis. Jakarta: PT Rineka Cipta.

Dewi, N.P.R.A. \& Ardani, I.G.A.K.S., 2016. Pengaruh Sikap, Norma Subjektif Terhadap Niat Beli Ulang Produk Fashion Via Online di Kota Denpasar. EJurnal Manajemen Unud, 5(1), pp.650-677.

Dwipayani, N.M. \& Rahyuda, K., 2016. Pengaruh Sikap dan Fashion Leadership Terhadap Niat Beli Online Remaja di Kota Denpasar. E-Jurnal Manajemen Unud, 5(6), pp.3620-3646.

Giantari, I.G.A.K., Zain, D., Rahayu, M. \& Solimun, 2013. The role of perceived behavioral control and trust as mediator of experience on online purchasing intentions relationship a study on youths in denpasar city (Indonesia). International Journal of Business and Management Invention, 2(1), pp.3038 .

Hellier, P.K., Geursen, G.M., Carr, R.A. \& Rickard, J.A., 2003. Custemer Repurchase Intention A general structura equation modell. Euroean Journal of Marketing, 37(11/12), pp.1762-1800.

iprice,2017.iprice.[Online]Availableat:https://iprice.co.id/insights/mapofecommer ce/ [Accessed 8 Augustus 2017].

Iwan, C.Y., 2013. Pengaruh Sikap terhadap Green Advertising pada Brand Image The Body Shop antara Konsumen Domestik dan Asing. Jurnal JIBEKA, 7(3), pp.5-10.

Jiang, P. \& Bert, R., 2005. Customer Intention to Return Online: Price Perception, Attribute-level Performance and Satisfaction Unfolding Over Time. International Journal of Marketing, 4(1), pp.20-30.

Kotler, P. \& Amstrong, G., 2008. Prinsip-Prinsip Pemasaran. Jakarta: Erlangga.

Kotler, P. \& Keller, 2012. Manajemen Pemasaran. 12th ed. jakarta: ideks.

Lazada, 2016. Lazada. [Online] Available at: https://www.lazada.co.id/about/ [Accessed 08 October 2016].

Maima, K.R., 2012. Analisis Pengaruh Kepercayaan Pelanggan dan Kualitas Pelayanan Terhadap Sikap Pelanggan dan Implikasinya Terhadap Keputusan Pembelian Ulang (Studi Kasus Pada CV.Mukti Manunggal Semarang). Diponegoro Business Review, 1(1), pp.1-7.

Mao, D., 2010. A Study of Consumer Trust in Internet Shopping And the Moderating Effect of Risk Aversion in Mainland China. Journal Manajemen, 1(1), pp.1-50. 
Mohmed, a.S.I., Azizan, B.n. \& Jali, Z.m., 2013. The Impact of Trust and past Experience on Intention to Purchase in E-commerce. International Journal of Engineering Research and Development, 7(10), pp.28-35.

Mowen, J.C. \& Minor, 2013. Perilaku Konsumen. Jakarta: Erlangga.

Ndubisi, N.O. \& Moi, C.T., 2005. Customers Behaviourial Responses to Sales Promotion: The Role of Fear of Losing Face. Asia Pacific Journal of Marketing and Logistics, 17(1), pp.32-49.

Nilasari, N.P.H. \& Kusumadewi, N.M.W., 2016. Peran Sikap Dalam Memediasi Pengaruh Kepedulian Lingkungan Terhadap Niat Beli Kosmetik Hijau Merek Body Shop. E-Jurnal Manajemen Unud, 5(1), pp.121-148.

Nofita, E.D., 2013. Analisis Faktor-Faktor yang Mempengaruhi Kepuasan Konsumen dalam Melakukan Pembelian pada Salwa House Cafe. Diponegoro Journal of Management, 2(2), pp.1-9.

Nusarika, L.A.K. \& Purnami, N.M., 2015. Pengaruh Persepsi Harga, Kepercayaan dan Orientasi Belanja Terhadap Niat Beli Secara Online (Studi pada Produk Fashion Online di Kota Denpasar). E-Jurnal Manajemen Unud, 4(8), pp.2380-2406.

Oliver, J.D. \& Lee, S.-H., 2010. Hybrid car purchase intentions: a cross-cultural analysis. Journal of Consumer Marketing, 27(2), pp.96-103.

Parastanti, G.P., Kumadji, S. \& Hidayat, K., 2014. Pengaruh Prior Online Purchase Experience Terhadap Trust dan Online Repurchase Intention (Survey pada Pelanggan ZALORA Indonesia Melalui Website www.zalora.co.id). Jurnal Administrasi Bisnis (JAB), 16(1), pp.1-7.

Reichheld, F.F. \& Sasser, W.E., 1990. Zero defections: quality comes toservices. Harvard Business Review, 98(5), pp.105-111.

Resti, D. \& Soesanto, H., 2016. Pengaruh Persepsi Harga, Kualitas Pelayanan Melalui Kepuasan Pelanggan Terhadap Minat Beli Ulang Pada Rumah Kecantikan Sifra Di Pati. Diponegoro Journal Of Management, 5(1), pp.1 12.

Sam, M.F.M. \& Tahir, M.N.H., 2009. Website Quality and Consumer Online Purchase Intention of Air Ticket. International Journal of Basic \& Applied Sciences IJBAS-IJENS, 9(10), pp.4-9.

Seock, Y.-K. \& Che-Yu, J.H., 2007. Website Evolution Criteria Among US College Student Consumer With Difference Shopping Orientation and Internet Channel Use. International Journal of Consumer Studies., 3(1), pp.204-212.

Suandana, N.P.W., Rahyuda, K. \& Yasa, N.N.K., 2016. Pengaruh Pengalaman Membeli Produk Fashion Terhadap Niat Membeli Kembali Nelalui 
Kenny Jaya Adinata, Pengaruh Kepercayaan....

Kepuasan dan Kepercayaan Pelanggan. Jurnal Manajemen, Strategi Bisnis dan Kewirausahaan, 10(1), pp.85-97.

Sugiyono, 2014. Metode Penelitian Bisnis. Bandung: Alfabeta.

Suprapti, N.W.S., 2010. Perilaku konsumen. Pemahaman dasar dan aplikasinya dalam strategi pemasaran. Bali: Udayana University Press.

Sutejo, B.S., 2006. Internet Marketing: Konsep dan Persoalan Baru Dunia Pemasaran. Jurnal Manajemen, 6 (1), pp.21-45.

Sutisna, 2001. Perilaku konsumen dan Komunikasi pemasaran. Yogyakarta: Liberty.

Thamizhvanan, A. \& Xavier, M.J., 2013. Determinants of customers' online purchase intention: an empirical study in India. Journal of Indian Business Research, 5(1), pp.17-32.

Tjiptono, F., 2004. Pemasaran Jasa. Malang: Bayumedia Publishing. 